\title{
The formation of multi-synaptic connections by the interaction of synaptic and structural plasticity and their functional consequences
}

\author{
Michael Fauth*, Florentin Wörgötter, Christian Tetzlaff \\ From The Twenty Third Annual Computational Neuroscience Meeting: CNS*2014 \\ Québec City, Canada. 26-31 July 2014
}

The connectivity between neurons - i.e., the number of synapses and their transmission efficacies (weights) determines information processing and storage in neural networks as, for instance, the cortex. Thus, in order to understand the functionality of cortical neural networks, we have to understand how they generate their connectivity. Along this line, there are two major mechanisms to modify connectivity: First, on a timescale of minutes to hours, synaptic plasticity (long-term depression or potentiation) adapts the transmission efficacies (weights) of existing synapses. Second, on a timescale of hours to days, structural plasticity creates and removes synapses. Hereby, the main influence is the volume of the dendritic spine [1] hosting the synapse. This volume is closely linked to the synaptic weight [2], which, in turn, is adapted by synaptic plasticity. All these mechanisms are influenced and determined by the activity pattern of the neural network. Hence, to understand how the connectivity of adult neural networks is adapted or maintained, it is important to understand the interaction of neural activity and the different plasticity mechanisms. In the following we will focus on one property of the cortical connectivity, namely the characteristic, bimodal distributions of the number of synapses connecting two neurons [3-5]. These distributions show high probabilities for two neurons to be either unconnected or connected with multiple (3-8) synapses.

To investigate how these distributions can emerge from the interaction between synaptic and structural plasticity, we use a probabilistic model, which captures the process of structural plasticity by abstracting it with weight-dependent probability functions. This allows us

\footnotetext{
* Correspondence: mfauth@gwdg.de

Third Physics Institute, Bernstein Center for Computational Neuroscience,
} University Göttingen, 37077, Germany
1. Yasumatsu N, Matsuzaki M, Miyazaki T, Noguchi J, Kasai H: Principles of Long-Term Dynamics of Dendritic Spines. J Neurosci 2008, 28:13592-13608.

Matsuzaki M, Ellis-Davies GC, Nemoto T, Miyashita Y, lino M, Kasai H: Dendritic spine geometry is critical for AMPA receptor expression in hippocampal CA1 pyramidal neurons. Nat Neurosci 2001, 4:1086-1092

Feldmeyer D, Egger V, Lübke J, Sakmann B: Reliable synaptic connections between pairs of excitatory layer 4 neurones within a single 'barrel' of developing rat somatosensory cortex. J Physiol 1999, 521(Pt 1):169-190. between layer 4 spiny neurone-layer $2 / 3$ pyramidal cell pairs in juvenile rat barrel cortex: physiology and anatomy of interlaminar signalling within a cortical column. J Physiol 2002, 538:803-822. 
5. Feldmeyer D, Lübke J, Sakmann B: Efficacy and connectivity of intracolumnar pairs of layer $2 / 3$ pyramidal cells in the barrel cortex of juvenile rats. J Physiol 2006, 575:583-602.

6. Markram H, Lübke J, Frotscher M, Roth A, Sakmann B: Physiology and anatomy of synaptic connections between thick tufted pyramidal neurons in the developing rat neocortex. J Physiol 1997, 500(Pt 2):409-440.

7. Turrigiano GG, Leslie KR, Desai NS, Rutherford LC, Nelson SB: Activitydependent scaling of quantal amplitude in neocortical neurons. Nature 1998, 391:892-896

8. Tetzlaff C, Kolodziejski C, Timme M, Wörgötter F: Synaptic scaling in combination with many generic plasticity mechanisms stabilizes circuit connectivity. Front Comp Neurosci 2011, 5.

doi:10.1186/1471-2202-15-S1-P186

Cite this article as: Fauth et al:: The formation of multi-synaptic

connections by the interaction of synaptic and structural plasticity and

their functional consequences. BMC Neuroscience 2014 15(Suppl 1):P186.

\section{Submit your next manuscript to BioMed Central} and take full advantage of:

- Convenient online submission

- Thorough peer review

- No space constraints or color figure charges

- Immediate publication on acceptance

- Inclusion in PubMed, CAS, Scopus and Google Scholar

- Research which is freely available for redistribution

Submit your manuscript at www.biomedcentral.com/submit 